\title{
多視点テニス画像からのプレーヤ視点画像の生成
}

\section{Video Synthesis of a Tennis Player's Viewpoint from Multiple View Videos}

\author{
木 村 健 二十, 正会員 斎 藤 英 雄 ${ }^{\dagger}$ \\ Kenji Kimura $^{\dagger}$ and Hideo Saito ${ }^{\dagger}$
}

\begin{abstract}
We propose a new method for synthesizing player viewpoint images from multiple view tennis videos. Our method uses two key techniques: virtual-view synthesis and player's viewpoint estimation. In the former, we divide the object tennis scene into sub-regions, which are the background, tennis court ground, players, and ball. For each sub-region, a virtual viewpoint image is synthesized by considering the geometrical conditions of each region. Then the virtual viewpoint images of the sub-regions are merged into a virtual viewpoint image of the whole scene. In virtual viewpoint image generation, view interpolation, which is a way of synthesizing images at an intermediate viewpoint to two views of the real object, restricts the viewpoint to a position between the two views. To avoid this restriction, we propose our first key technique, whereby we are able to flexibly position the viewpoint. In our second technique, the viewpoint is computed using epipolar geometry from the center of gravity of a player. By applying the computed player's viewpoint to the former technique, we can synthesize player viewpoint images. Experimental results demonstrate that the proposed method can successfully provide a video of the tennis player's viewpoint from multiple-view video images.
\end{abstract}

キーワード : ブレーヤ視点, 自由視点映像, 射影幾何, トラッキング, 多視点映像

\section{1. ま え がき}

近年, スポーツ等の放送映像に対して, 特殊な映像効果 を付与する試みが盛んになっている，例えば，テニスにお けるボールの追跡を行い, CG に重畳表示して自由な視点

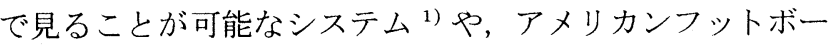
ルのスーパーボウル中継において，同一シーンを 30 台以 上のカメラで撮影し，それらを連続的に切り替えて提示す る映像効果を持つ EyeVision システムなどが挙げられる. 一方, Computer Vision の分野では, 多数のカメラにより 撮影したスポーツ映像から, 自由に指定された仮想視点に おける映像を生成することを目的とした研究が行われてい $ろ^{2)}$.

複数のカメラ画像から仮想視点画像を生成する手法 は, Image Based Rendering(IBR) と呼ばれる. IBR は, Model Based 手法と Transfer Based 手法に分けられる. Model Based 手法は, 3 次元モデルを復元して, テクス チャーを貼り付けて仮想視点画像を生成する手法2)3) である.

一方, Transfer Based 手法は入力画像間の対応点を仮

2003 年 12 月 18 日, 電子情報通信学会P RMU研究会で発表 2004 年 3 月 1 日受付, 2004 年 5 月 25 日再受付, 2004 年 7 月 9 日採録 †慶応義塾大学 情報工学科

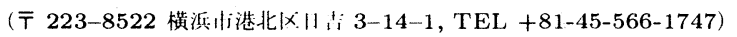
† Department of Information and Computer Science, Keio Univ. (3-14-1, Hiyoshi Kouhoku-ku Yokohama 223-8522, Japan)
想視点に移動して，仮想視点画像を生成する手法であり， View Interpolation ${ }^{6)}$, View Morphing ${ }^{7)}$ 等が代表的な手 法として知られている。これらの手法では, 入力画像間で 画素の対応関係が必要である。この対応関係を多視点画像 から自動的に求めるために対象の 3 次元モデルを復元し, Transfer Based 手法により仮想視点画像を生成する手法 ${ }^{5)}$ が提案されている. また, 多視点画像から 3 次元モデルを 復元するためには, シーンの 3 次元座標系とカメラ座標系 の射影関係を推定する強校正を行う必要があるが，その空 間が大きくなるほど，その作業は困難となる. そこで, こ れを軽減するために，カメラ間の射影幾何関係のみを推定 する弱校正を行うだけで 3 次元モデルを推定し, 仮想視点 画像を推定する手法 ${ }^{4)}$ も提案されている.

この Trasnfer Based 手法に基づいた IBR を, サッカー シーンを全体に対して適用し，仮想視点画像を生成する手 法が稲本ら ${ }^{8)}$ よって提案されている. この手法では, サッ カーシーンをグラウンド面と背景シーンの静止領域, そし て, 選手とボールの動領域に分け, 入力画像の各領域毎の 特徵に応じて, カメラ間の射影幾何関係を利用し, 仮想視 点画像を生成する.この手法では，カメラ間の射影幾何関 係を求める弱校正を行うだけで良いので, サッカーのよう な大規模空間におけるスポーツシーンに対しても, 容易に 適用可能である. また，シーンをその幾何学的性質に応じ て分割し, 各領域毎に仮想視点画像を生成して, それらを 
合成するという方法であるため, サッカーシーン全体につ いて仮想視点画像を生成することに成功している.

本論文では, この稲本らの手法 ${ }^{8)}$ をテニスに拡張して利 用することにより，テニスのプレーヤ視点における仮想視 点画像を生成する手法を提案する. 本手法では, テニスの プレーヤ位置を複数のカメラで追跡し，このプレーヤ位置 における仮想視点画像を生成する. そして, 本手法をテニ スの多視点画像に適用することにより，本手法の有効性を 示寸.

稲本らの手法 ${ }^{8)}$ では, Transfer Based 手法の一つであ る, View Interpolation ${ }^{6}$ に に基づいて仮想視点画像を生成 している.この手法は，二つの入力視点画像に対する内挿 比によって仮想視点を指定するため, 仮想視点の移動が入 力視点間に制限されるという問題があり, そのままテニス に適用しただけでは, 追跡したプレーヤ位置に扔ける仮想 視点画像を合成することができない，そこで，提案手法で は, 内挿比を使わずに，自由に視点位置を設定でき，そし て視点の位置を直接指定できる新しい手法を用いる. 具体 的には, 指定された仮想視点と入力視点画像の $\mathbf{F}$ 行列を用 いて仮想視点画像を合成する。これにより，仮想視点の自 由度が制限されず，追跡したテニスプレーヤ位置における 仮想視点画像を自由に生成できる。な扔本手法では，この 仮想視点と入力視点の $\mathbf{F}$ 行列算出のために, テニスコート 形状の規格を利用する。

多視点画像からの仮想視点画像生成法をスポーツ画像に 利用して得られる効果の一つとして, 競技中のプレ一ヤの 視点における画像提示が考えられる.しかし，従来研究で は，実際にプレーヤ視点画像を生成するにまでには至って いない. 本研究では, このプレーヤ視点における画像生成を 実画像から行っているという点も特徵の一つになっている.

\section{2. 射 影 幾 何}

\section{1 射影行列}

図 1 に示すようなカメラモデルにおいて，3 次元空間で の座標 $\mathbf{X}$ とその画像上に投影された座標 $\mathbf{m}$ との関係は, 射影行列 $\mathbf{P}$ によって記述される。

$$
\begin{aligned}
\tilde{\mathbf{m}} & =\mathbf{P X}_{\mathbf{w}} \\
\mathbf{P} & =\left(\begin{array}{ccc}
f & 0 & u_{0} \\
0 & f & v_{0} \\
0 & 0 & 1
\end{array}\right)[\mathbf{R} \mid \mathbf{T}]
\end{aligned}
$$

ただし, $f$ は焦点距離, $\left(u_{0}, v_{0}\right)$ は画像中心， $\mathbf{R}$ は回転行 列， $\mathbf{T}$ は並進行列である.

\subsection{F 行列}

複数の視点における相対的なカメラの位置や姿勢の情報 はエピポーラ幾何によって記述できる. 図 2 に示すように, 空間上の点 $\mathbf{X}$ と $\mathbf{m}$ を結ぶ線を視点 2 に投影した線上に, 視点 1 の点 $\mathbf{m}$ の対応点が存在することになる.この投影

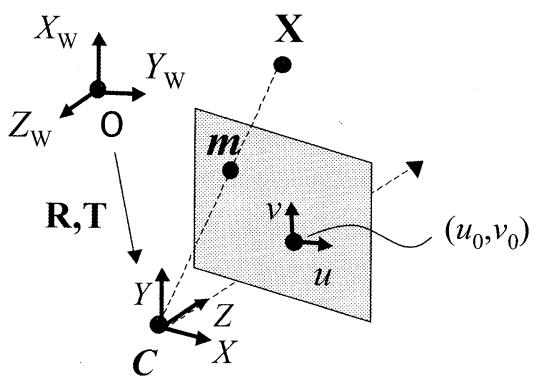

図 1 カメラモデル

Camera model.

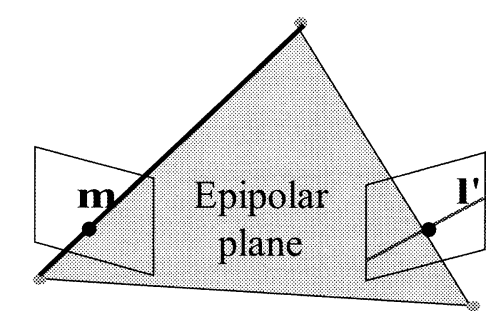

View1

View2

図 2 エピボーラ幾何

Epipolar geometry.

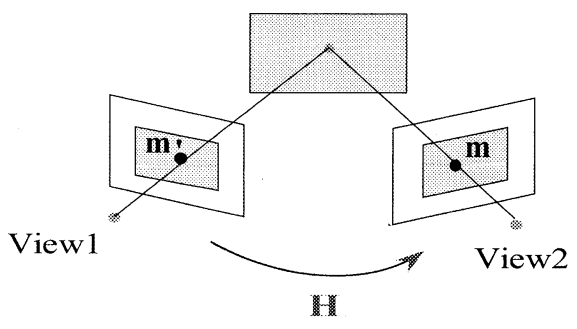

図 3 ホモグラフィ

Homography.

された線のことをエピポーラ線と呼び, 対応点の探索領域 を制限することができる，そして，エピポーラ線 $\mathbf{l}^{\prime}$ は次の ようにして求めることができる.

$$
\mathbf{l}^{\prime}=\mathbf{F} \tilde{\mathbf{m}}
$$

ここで $F$ は Fundamental Matrix(F 行列) と呼ばれ, 既 知な対応関係から算出することができる.

\subsection{H 行列}

空間中である平面上の点は, その平面において一意に決 まる行列 $\mathbf{H}$ によって，画像間の 1 対 1 の対応関係を得る ことができる (図 3).

$$
\tilde{\mathbf{m}}^{\prime}=\mathbf{H} \tilde{\mathbf{m}}
$$

ここで $\mathbf{m}, \mathbf{m}^{\prime}$ は 2 視点で対応する点同士である. また $\mathbf{H}$ は Homography $(\mathbf{H}$ 行列 $)$ と呼ばれ, この平面上の点にお ける既知な対応関倸から算出することができる.

\section{3. 提 案 手 法}

図 4 に本手法の流れを示す，本手法では，対象テニスシー ンをグラウンド面と背景シーンの静止領域, そして, 選手 とボールの動領域に分け, 領域毎に仮想視点画像を生成し, 最後にすべての領域を合成することにより, シーン全体の 


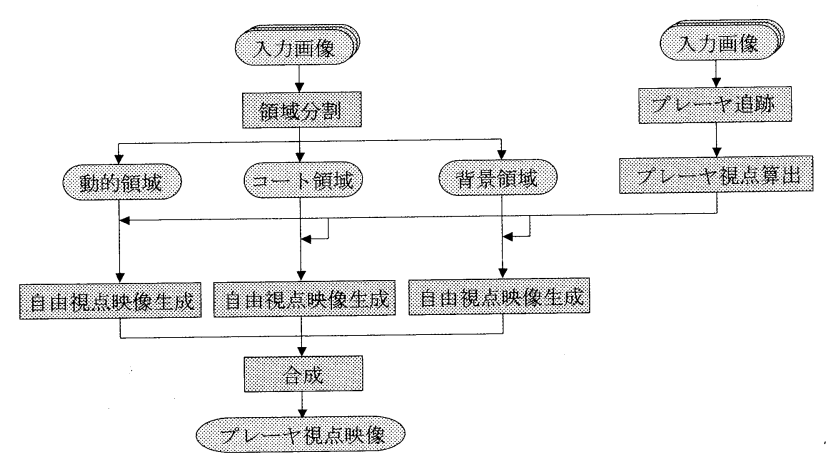

図 4 本手法の流れ

Flowchart of proposed method.

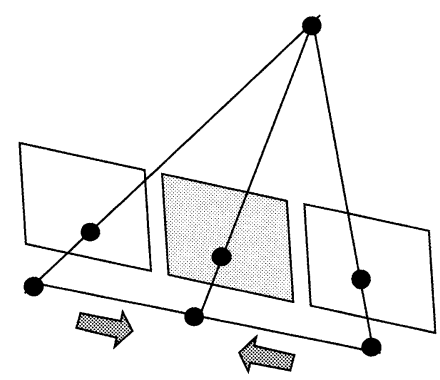

図 5 View Interpolationに抢ける対応点の移動

Transfer of corresponding points in View Interpolation.

仮想視点画像が生成される。一方, 別途設置されたカメラ により追跡したプレーヤ視点によって仮想視点位置を指定 することによって，プレーヤ視点画像を生成する.

\section{1 動領域に対する仮想視点画像生成}

動領域に対しては，Transfer Based 手法を用いて画像 を合成することで仮想視点画像を生成する。この Transfer Based 手法には，異なる 2 視点での画像からそれらの中間位 置での画像を合成できる手法である View Interpolation ${ }^{6}$ がある。この View Interpolation では，2つの入力画像の 内挿比を指定し，2つの入力画像間の対応点の移動量を内 挿することにより，仮想視点画像上での対応点の位置を決 定する. そして，この位置に入力画像の画素值を与えるこ とを，入力画像間のすべての対态画素について行うことに よって, 仮想視点画像が生成される。

このとき，View Interpolation では，図 5 に示すように 二つの入力画像の内挿比により，仮想視点位置を決定する ため, 仮想視点位置の設定範囲が二つの入力画像の視点を 結んだ直線の間に制限される。これに対して，本手法では， 二つの入力画像の内捙比ではなく, 推定されたプレーヤ位 置に応じて，仮想視点の位置や姿勢を指定できなくてはな らない，そこで本手法では，指定された仮想視点から算出 される，仮想視点と入力画像間の $\mathbf{F}$ 行列によって仮想視点 画像を合成する.

図 6 のように，任意に指定された仮想視点に対して，二 つの入力画像に対寸る二つの $\mathbf{F}$ 行列を与えたとき，二つの 入力画像間の対応点が，仮想視点上ではエピポーラ線の交 点に対応することになる．そこで，二つの入力画像間のす 心゙ての対応点の画素值を，仮想視点上でエピポーラ線の交

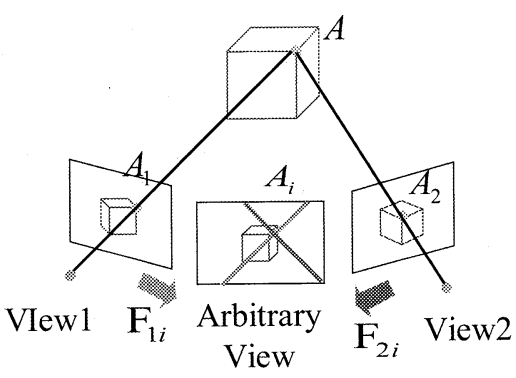

図6 本手法の対応点の移動

Transfer of corresponding points in the proposed method.

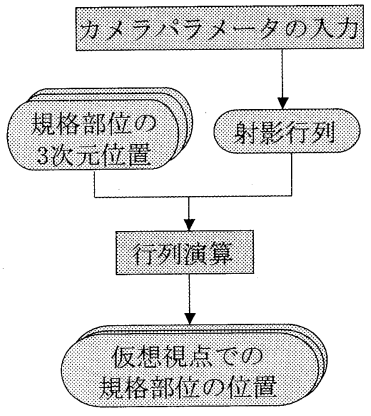

図 7 規格部位の仮想視点での位置算出

Estimation of the position in the virtual view image of standard parts.

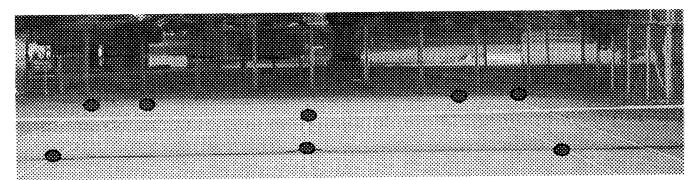

图 8 テニスコートの規格部位

Standard parts on tennis court.

点に与えることによって，仮想視点画像が生成できる，

このように，動領域に対する仮想視点画像生成のために には, 仮想視点と入力画像間の $\mathbf{F}$ 行列, そして, 入力画像 間の画素毎の対応関係が必要である. 仮想視点と入力画像 間 $\mathbf{F}$ 行列は，テニスコートの規格を利用して推定する．ま た, 入力画像間の画素毎の対応関係については, 選手とボー ルに分け，領域毎に推定する. 以下に，これらの推定方法 の詳細について述べる。

（1）仮想視点と入力画像の $\mathbf{F}$ 行列の推定

仮想視点の位置と姿勢が与えられると，(2) 式の $\mathbf{R}$ と $\mathbf{T}$ が決定される. 仮想カメラの焦点距離 $f$ は任意に与える. すると，仮想カメラの射影行列を算出できる．そして，こ の仮想カメラの射影行列から，図 7 に示寸ようにして，テ ニスコート特有の規格により，3 次元位置が既知な点 (図 8) が，仮想カメラ上に投影される位置を算出することができ る.一方，これらの規格部位が入力画像に撮影されている 点を，事前に手動により指定しておけば，規格部位に関す る, 仮想カメラと入力画像の対応関係が得られる.この対 応関係により，入力視点と仮想視点との間の $\mathbf{F}$ 行列を算出 することができる，つまり本手法では，このように仮想視 点の位置, 姿勢を直接指定することにより, 前後/左右/上 下，パン/チルト/ローと自由に視点を変化させることがで きる。
(151) 1505 

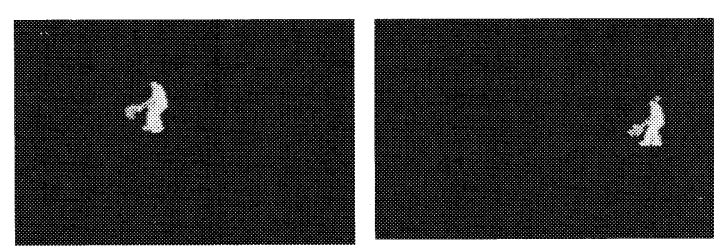

(a) 背景差分

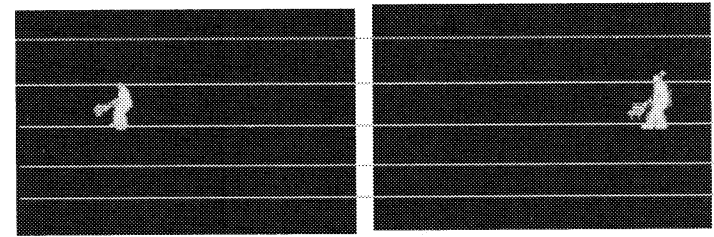

(b) エヒホーラ線平行化

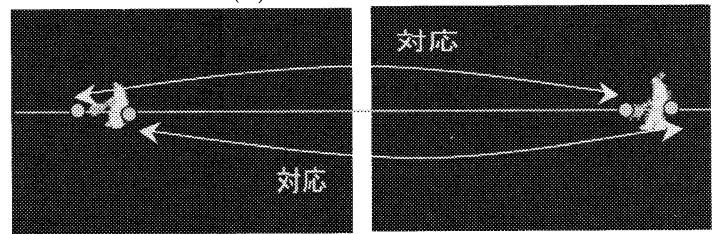

(c) エッジ対灾づ!

図 9 選手領域の対忘ゔ!

Matching player domain.

（2）動領域におうける画素䇤の対応関係の推定

テニスシーンの動領域は，選手領域とボール領域である。 これらの領域に対しては，各フレームについて画素解の対 态関係を求め, フレーム每に仮想視点画像を合成寸る.

\section{[選手領域の対応関係]}

選手領域を抽出するため，背景差分を行って選手のシル エット画像を得る。次にそれらのシルエット画像間でエヒ ボーラ線の平行化を行い, 対志点が同じスキャンライン上 に存在するようにする。乙して，同じスキャンライントで エッジ同士の詨忘付け ${ }^{9)}$ 在行い，シルエット内部に関して は図 9 に示寸ようにして，エッジ間の対态関係の線形補間 によって，画素毎の対応付けを行う。

\section{[ボール領域の対応関係]}

ボール領域を抽出するため，前フレームと現フレーム間， 闃フレームと次フレーム間でフレーム間差分を行う。それ ぞれで得られたシルエット間でAND 処理を施すことによっ て，背景除去画像を生成寸る ${ }^{10)}$. しかし，これだけではボ一 ル以外の領域もまだ残っている状洗なので，そのシルエッ 卜内の人力画像の色情報を用いて，最も黄色らしいラベル をボール領域として抽出する。次にボール領域の重心を求 め，それらを画像間で対応づけを行う(図 10).

\section{2 静止領域での処理}

静止領域 (図 11) では、テニスコートの規格部位を利用 して，仮想視点画像を生成する。

まず，コート・ネットは，これらの頂点の 3 次元位犆がテ ニスコートの規格により既知なので，この頂点位置が仮想 視点画像に投影される位置は， 3.1 ( 1 ) と闹様の方法によ り決定可能である。一方，闹じ点の入力画像上の点は，女 らかじめ手動で抽出しておくことより決定できる。コート

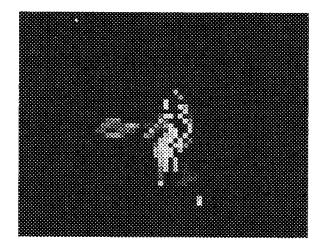

(a) フレーム間差分

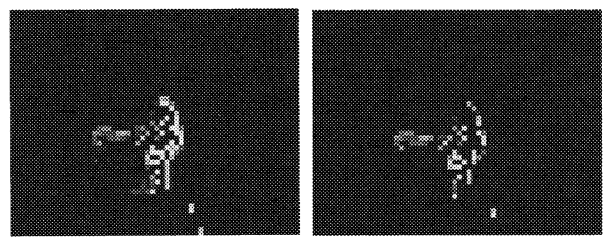

(b) AND 処理

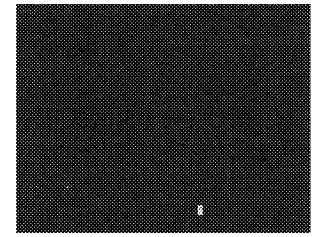

(c) ボーール抽出

图 10 ボール領域つ抽出

Extraction of ball region.
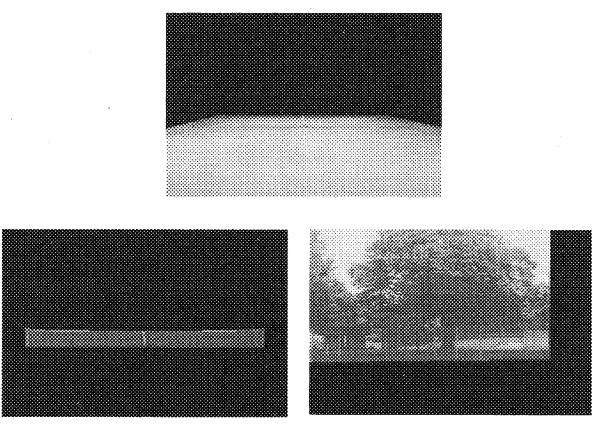

図 11 分割された静止領域 Divided static regions

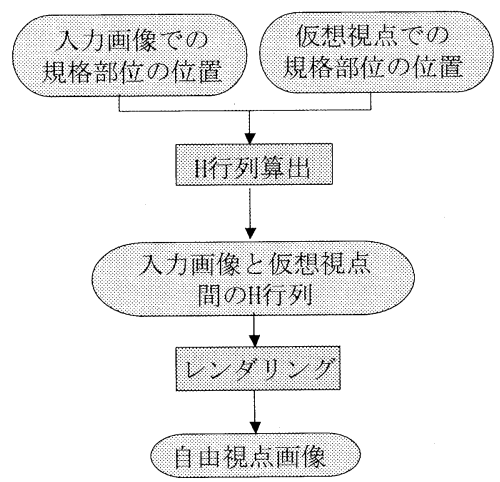

図 12 静止頒域ひ処理の流れ Flow of processing for static domain

・ネットは，ともに平面であるため, 仮想視点と入力画像間 の対志点から推定可能なホモグラフィを用いて，仮想視点 に対応点を移動寸れば，仮想視点画像を生成することがで きる(図 12).

-一方，背舅はㄱ.つつ平面と見な寸ことができるほど遠方 に存在寸るものと見なし，同様にホモグラフィを推定し，こ れを利用して背景の仮想視点画像を生成できることになる。 


\section{3 プレーヤ視点推定}

プレーヤ視点位置は, 2 台のプレーヤ視点推定用カメラに より撮影される画像により推定する. 本研究では, すべて のカメラの強校正は行わないものとする。これは，テニス コートのような大規模な空間でカメラの強校正を行うこと は非常に面倒であり，労力を要するものだからである，そこ で, 提案手法では，撮影された画像だけから得られる射影 幾何情報のみを用いてプレーヤ視点を推定する．また，選 手が実際に見ている本当の視線方向や，選手の眼の厳密な 3 次元的位置をプレーヤ視点推定用カメラにより追跡する のは困難である，そこで，選手の視点の高さがテニスコー 卜面から一定の高さにあり, 常に対戦相手の方向に視線を 向けているという仮定のもとで, プレーヤ視点推定用カメ ラの画像からプレーヤ視点を決定するものとする.

具体的な処理法は，まず，プレ一ヤを背景差分によって抽 出した後，画像上でのプレ一ヤ足元座標を算出する．そし て，グラウンド面に括けるテニスコートの頂点座標と，そ れらのプレ一ヤ追跡用カメラ上での座標の対応関係から推 定されるプレーヤ追跡用カメラとグラウンド面のホモグラ フィを用いて，グラウンド面におけるるプレ一ヤ足元座標を 算出できる．この足元座標の 3 次元位置に定数で与えた高 さ成分を付加したものをプレーヤの視点位置とする.

このとき, 単純に背景差分して抽出された領域の最下点 を足元座標としてしまうと，(1)背景差分によって足の部分 が切れてしまったとき，(2)プレーヤがジャンプしていると きに，大きな誤差が生じてしまう。また画像フレームによっ て異なる足を検出してしまうことにより，実際のプレーヤ の進行方向とは逆方向に動いたように推定されてしまうこ ともある。一方，両足を検出してその平均を足元座標とし ても，ラケットのような部分を足と誤認識してしまうこと もある。そこで本手法では，プレーヤ領域に関して最も安 定して求められる要素と考えられる重心を，2台のプレー ヤ視点推定用カメラにより検出し，この重心から足元座標 を次のようにして求める。

まず，図 13 に示すように，“プレ一ヤ視点推定用カメラ に撮影されたプレ一ヤの軸は，打打よそ画像の垂直軸に平 行であるように撮影されている”という仮定をする。これ は，プレーヤがグラウンド面に対して垂直に立っており，プ レ一ヤ追跡用カメラの水平軸がグラウンド面に平行である ことに相当し，実際の撮影画像において充分に現実的な仮 定と言える。この仮定によって，プレ一ヤの重心から垂直 方向に下ろした線上に足元座標があると見なせ，かつこれ らの足元座標は， 2 視点のプレーヤ視点推定用カメラ画像 間で対応していると考えることができる，そこで，図 14 に 示すように，画像上で重心を通る垂直な直線を引き，これ を，プレーヤ視点推定用カメラとグラウンド面のホモグラ フィを用いてグラウンド面上に投影する。この直線を二つ のプレーヤ視点推定用カメラについて求め, これらの交点

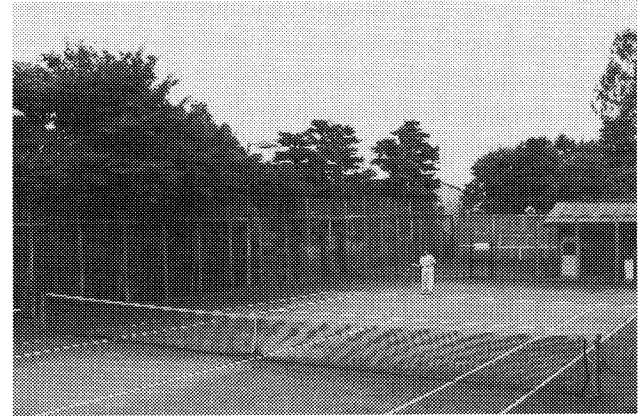

図 13 仮定老満た寸上うな入力画像例 An input image which fills assumption.
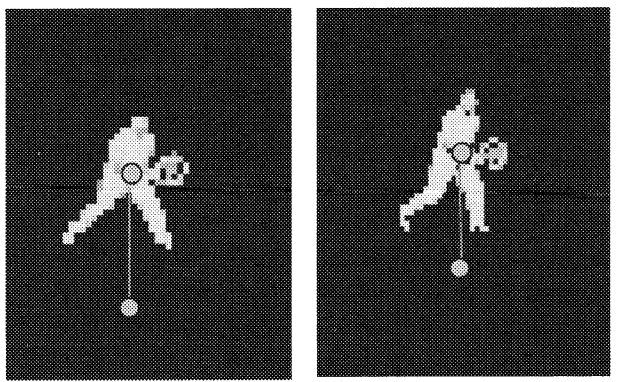

図 14 重心から下ろした重線 Vertical line from the center of gravity.

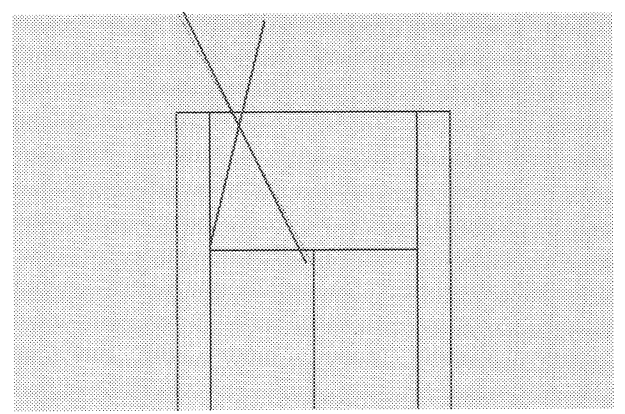

図 15 グラウンド面上に投影された線の交点 Intersection of the line projected on ground plane.

を取ると，図 15 のようにプレーヤの足元座標を得ること ができる.

このような手法を用いると，上記の(1)ような症例が起 きたとしても，重心は全体でその誤差を分散するのでその 影響は小さい，また，(2)ような場合も重心から地面に接 している部分を直接求めることができるので，問題は生じ ない.

上記のように, 本手法では, 高さ成分に関しては一定と 見なしているので，厳密なプレ一ヤの視点は求めていない． しかし，プレーヤの視点を直接求めるより，足元座標から 求めた方がフレーム間でのプレーヤの相対的な運動を安定 して再現することができ，プレーヤ視点の画像においてな めらかな変化を実現できる.

\section{4. 実 験}

テニスを多視点から撮影し，プレーヤ視点画像を生成す ることを試みた。 図 16 に示すように, 仮想視点画像生成 


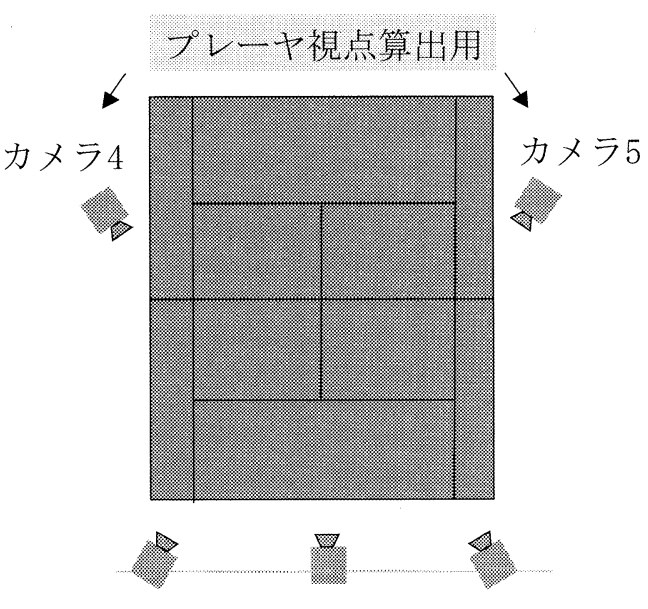

カメラ 1 カメラ 2 カメラ 3

自由視点画像生成用

图 16 力メラ配置

Locations of cameras.

用カメラ 3 台とプレーヤ視点推定用カメラ 2 台を設置し, さらにコート・背景などを撮影している 1 枚の静止画像も 使用した．入力画像は， $720 \times 480$ 画素，RGB24bitの力 ラ一画像であり, 図 17 にその一例を示す.

まず，プレーヤの視点算出結果を検証する (図 18). シル エットの最下点を足元座標としたときの結果を見ると，プ レーヤは右斜め前 (プレーヤ自身から見て)に移動している にもかかわらず，逆方向に動いたような結果が出ている部 分があり，また追跡されたプレ一ヤ軌跡がランダムに動い て推定されている。これは異なるフレームで左右異なった 足を検出してしまうことが原因と考えられる。一方，本手 法では，検出したプレ一ヤ領域の重心を用いてプレーヤ位 置を算出することによって，プレーヤの動きに忘じた軌跡 が推定できていることがわかる.

次に本手法により生成した仮想視点画像の結果を検証す る.図 19 に，比較のために，View Interpolation を拡張 した手法である View Morphing8) を用いて生成した仮想視 点画像を示す。ここでView Morphing とは, View Interpolation が持つ幾何学的な歪みの発生という久陥を回避す るするために, 前処理として入力画像面の平行化を行った 上で画像を合成する手法である。しかし，View Morphing は，本質的にはView Interpolation と同等で，入力視点間 の内择比で仮想視点は指定される. 図 19 を見ると, View Morphing では，仮想視点は入力視点位置を結んだ直線上 にしか設定できないため, プレーヤ視点の画像を生成する までには至らないことが確認できる。一方，本手法を用い て実際にプレーヤ視点の画像を生成した結果 (図 20) を見 ると,コート上に存在するブレーヤの視点に扔ける画像を 生成できていることがわかる，また，図 21 には，コート上 の色々な場所を指定して本手法により生成した仮想視点画 像を示す。このように，本手法ではコート上の自由な位置 におうける仮想視点画像を生成できていることが確認できる.

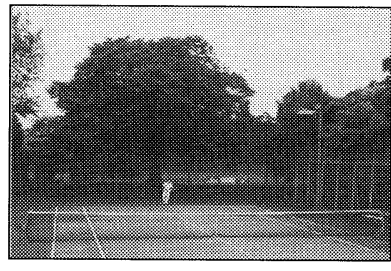

(a) カメラ 1

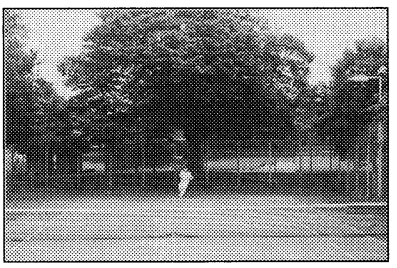

(b) カメラ 2

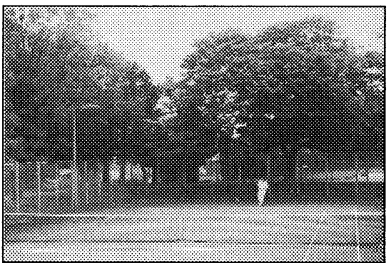

(c) カメラ 3

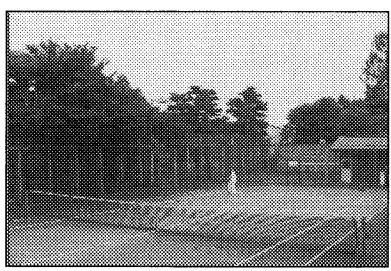

(d) カメラ 4

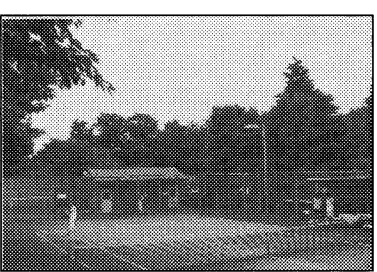

(e) カメラ 5
図 17 入力画像

Input images.

\section{5.むすび}

テニスの多視点画像からプレーヤ視点画像を生成した. このとき, 視点の移動が入力視点間に限定されていた View Interpolationに対し, 本論文では仮想視点位置を自由に設 定可能な新しい手法を提案した。一方で，射影幾何を用いた 効率的かつロバストなプレーヤ視点の算出法も同時に提案 した. プレーヤに㧍ける安定した要素である重心を介して 求めることで, 安定した算出結果を得ることを可能にした.

今回の実験は, 本手法が適用可能な必要最低限のカメラ 台数で行ったものである. そのため, カメラ設置台数の追 加とそれに伴う画像の高精度化についての検討が今後の課 題である. 


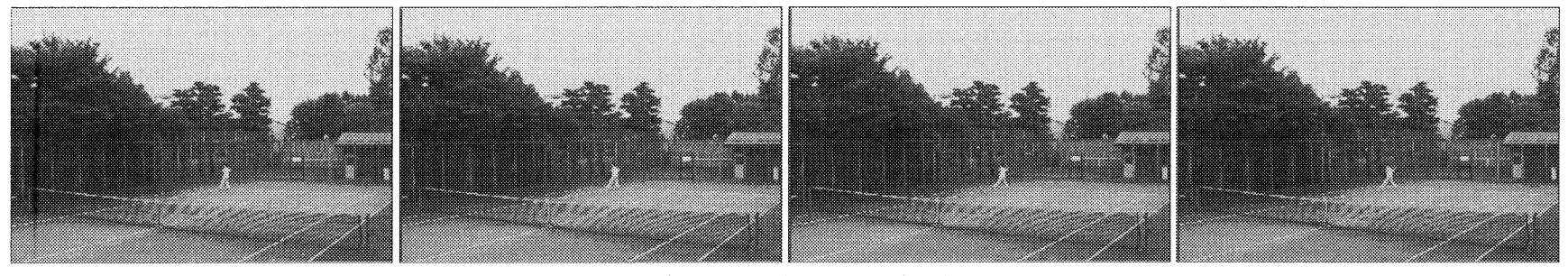

(a) プレーヤの動きを示す実画像
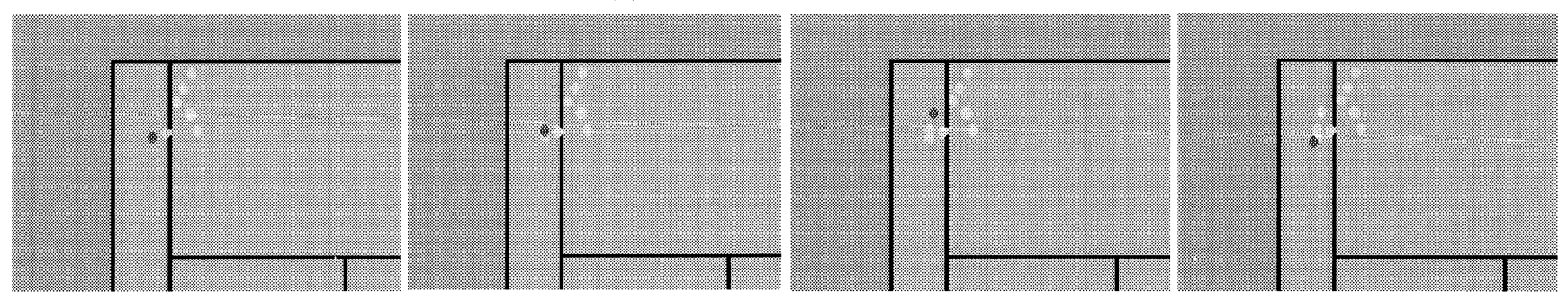

(b) 最下点を足元座標としたときの追跡結果 (白:過去の軌跡, 黒:現在)
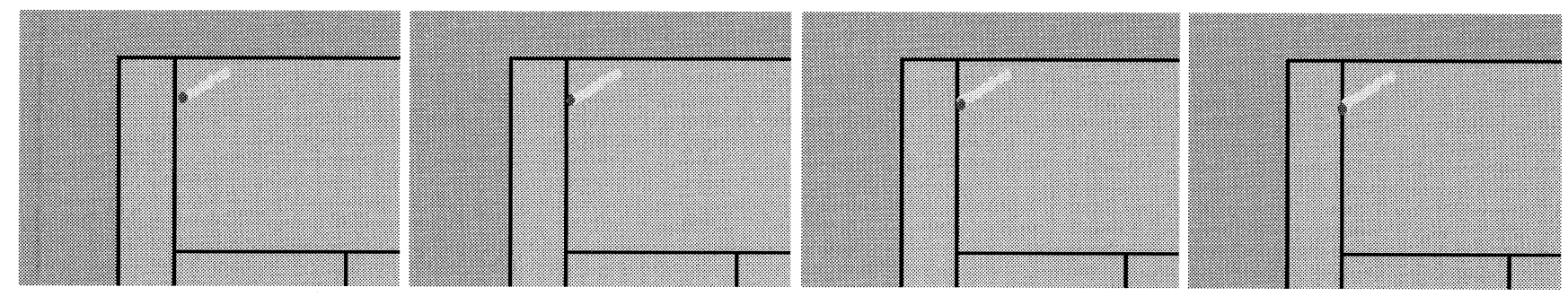

(c) 本手法の重心を利用した追跡結果 (白:過去の軌跡, 黒:現在)

図 18 ブレーヤ視点算出結果

Results of player-viewpoint estimation.

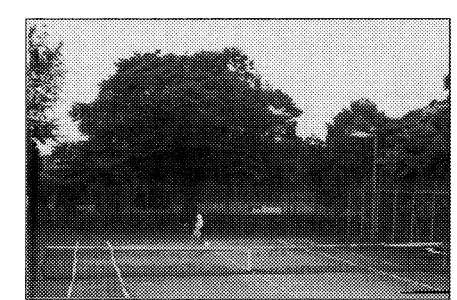

(a) $1: 9$

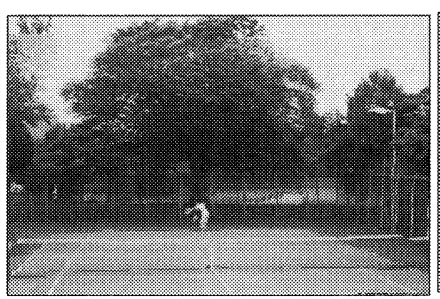

(b) $4: 6$

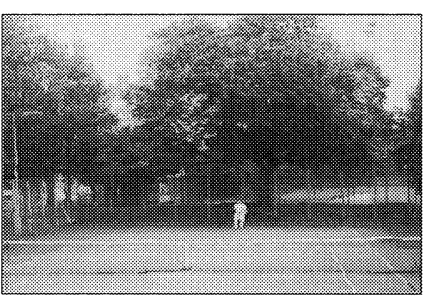

(c) 6:4

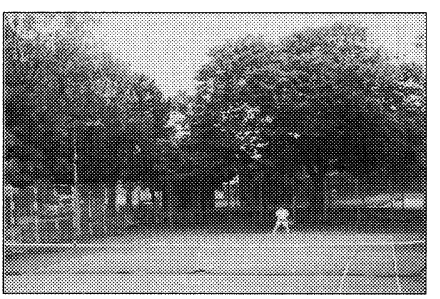

(d) 9:1

图 19 view morphing による仮想視点画像

Virtual viewpoint images using View Morphing.
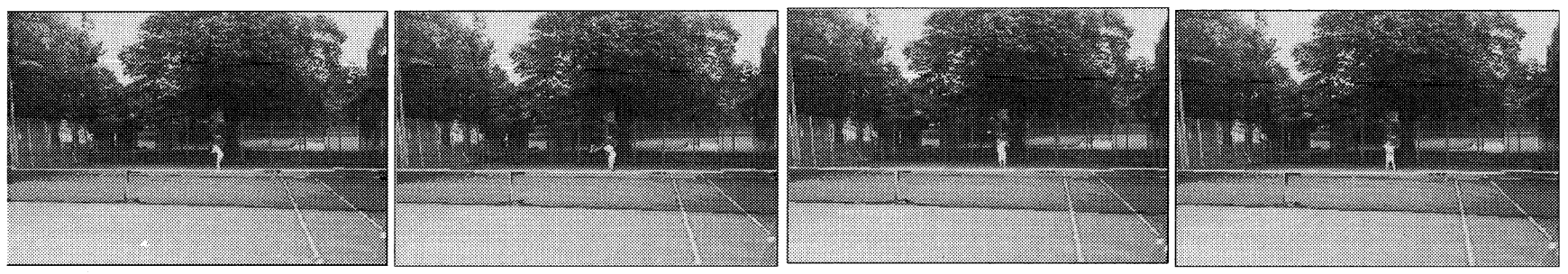

(a) 実際に生成されたブレーヤ視点画像
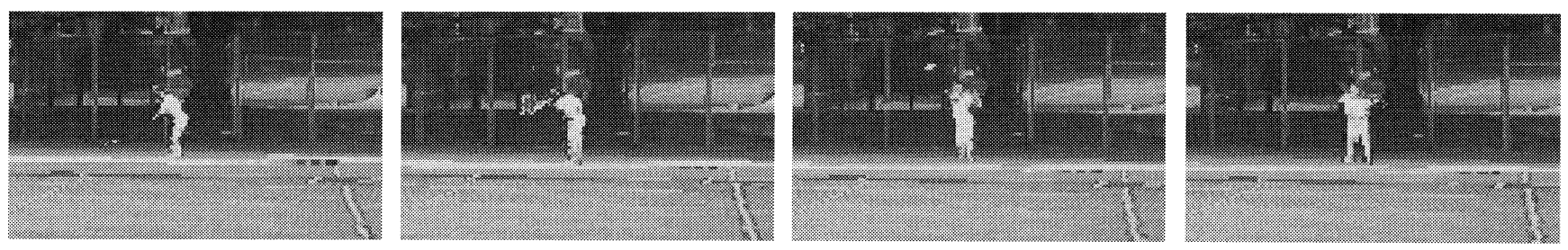

(b) ブレーヤ付近を拡大した画像

图 20 本手法によるプレ一ヤ視点画像

Player-viewpoint images using our technique. 


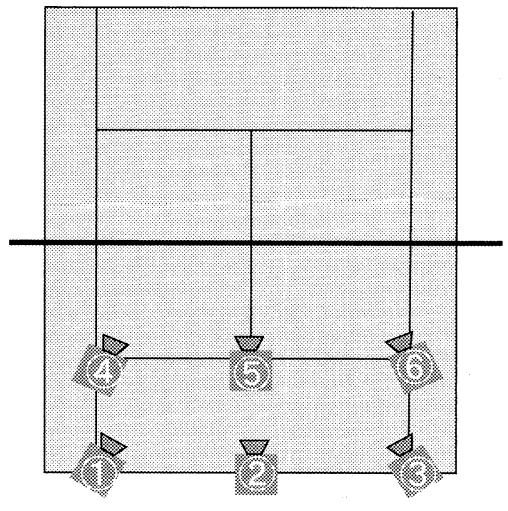

(a) 視点人力位置
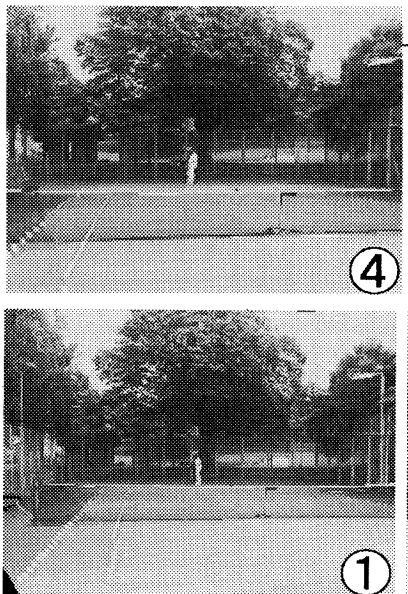

图 21 本手法による仮想視点画像

Virtual viewpoint images using our technique.
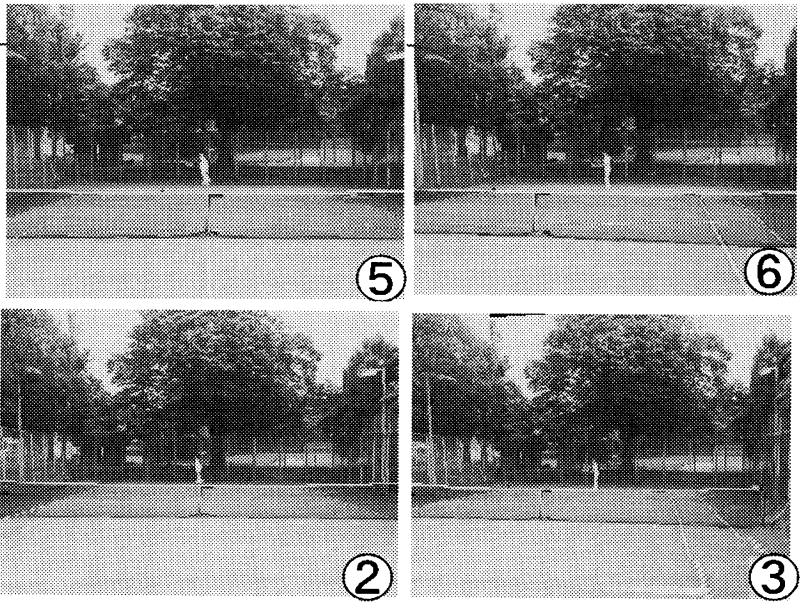

\section{[文献]}

1) Gopal Pingali, Agata Opalach, Yves Jean, "Ball Tracking and Virtual Replays for Innovative Tennis Broadcasts", ICPR'00,Volume 4(2000)

2）北原格, 大田友一, ”多視点映像の融合によるスボーツシーンの自由視 点映像生成”，信学技法, PRMU2000 - 189, pp23-30（2000）

3) T.Kanade, P.J.Narayanan, P.W.Rander, "Virtualised Reality: Concepts and Early Results" , IEEE Workshop on Representation od Visual Scenes, pp69-76 (1995)

4）矢口悟志, 木村誠, 斎藤英雄, 金出武雄, “未校正多視点カメラシステム を用いた任意視点画像生成,”情報処理学会コンピュータビジョンとイ メージメディア研究会論文誌, Vol.42, No.SIG06-003, pp.9-21 (2001)

5) H.Saito, S.Baba, T.Kanade, "Appearance-Based Virtual View Generation From Multicamera Videos Captured in the 3-D Room," IEEE Trans. on Multimedia, vol.5, no.3, pp.303-316 (2003)

6) S.E.Chen, L.Williams ,"View interpolation for image synthesis", Proceedings of SIGGRAPH '93,pp279-288 (1993)

7) Seitz,S.M. and Dyer, C.R., "View morphing" , Proceedings of SIGGRAPH' '96,pp.21-30 (1996)

8）稲本奈穂, 斎藤英雄, ”視点位置の内挿に基づく 3 次元サッカ一画像の自 由視点鑑賞システム”，映像情報メディア学会誌，Vol.58, No.4 (2004)

9) S.Pollard, M.Pilu, S.Hayes, A.Lorusso, "View Synthesis by trinocular edge matching and transfer", Image and Vision Computing 18, pp 749-757 (2000)

10）渡部周平, 斉藤英雄, ”テニスにおうける複数のカメラを用いたボールの 追跡”, 電子情報通信学会 2003 総合大会, D-12-114（Mar. 2003）

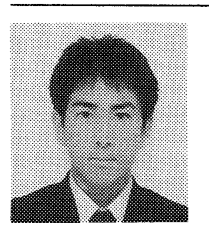

导村 健亡 2004 年慶應義塾大学理工学部情報工 学科卒業. 現在, 同大学大学院理工学研究科修士課程開 放環境科学専攻に在学中.コンピュータビジョンに関す 万研究に従事.

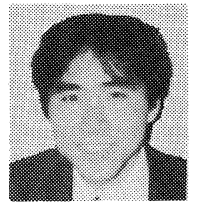

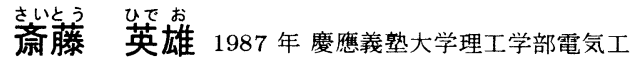
学科卒業. 1992 年 同大学大学院博士課程修了卒業. 同 年同大学助手, 専任講師老経て 2001 年 助教授.コン ピュータビジョン, 画像処理等に関する研究に従事. 1997 年から 1999 年まで, 日本学術振興会海外特別研究員と して米国カーネギーメロン大学に留学. 2000 年より, 科 学技術振興事業団さきがけ 21 (「情報と知」領域) 研究 員兼任. 工学博士. 正会員. 